have seen in the Midland Counties. Thick beds of sand and gravel, containing fragments of Shells, occur to the north of Hodnet.I am, \&c.

George Maw.

Benthall Hall, near Broseley : Oct. 22, 1864.

\title{
DISCOVERY OF THE SKELETON OF LEIODON ANCEPS IN THE CHALK AT NORWICH.
}

To the Editors of the Geological Magazine.

AT the base of the high hill enclosed by the boundary of St. Leonard's Priory are some extensive chalk-pits, which, from having been described in Cunningham's Map of Norwich as 'the place where men are customably burnt,' are now known as Lollard's Pit. From the large quantity of chalk yearly removed from this spot, a greater number of the Chalk fossils in the hands of the Norwich collectors are obtained from these pits than from others in the neighbourhood. In 1858 a few vertebræ of Leiodon anceps were discovered, and identified by a tooth which was in their immediate proximity. During the past week a number of bones of the same skeleton have been discovered, including about 6 vertebra, a hundred fragments of other bones, and 4 teeth, two of which are the large cultrate two-edged teeth so much in request among collectors, and two are of the smaller kind from the inner part of the mouth.

It is much to be regretted that so interesting a specimen is in so delicate a state that the bones can only be extracted in fragments; but, however the collector may be disappointed, to the Palæontologist this discovery is a ray of hope that at some future time a better preserved specimen may be discovered.-Yours truly,
Norwich: Oct. 20, 1864
T. G. BAYFIELD.

\section{MISCELIANEOUS.}

There has lately been found, and added to the national collection, in the valley-gravel near Vauxhall, south of London, a skull of Bos frontosus, Nilsson, nearly entire, and having the characteristic downward curve of the horn-cores. The frontal, maxillary, and palatine bones are nearly perfect, and there are six molar teeth in sitû. This is the second instance of this species being met with in England. The other specimen was from the Bawdsey Bog, near Felixstow, Suffolk, and was figured in the 'Geologist' for 1862, pl. 15, p. 441. Both the skulls exhibit similar points of difference from the cast of the typical Bos frontosus described by Professor Nilsson in K. Vetensk. Akad. Öfversigt, 1847, p. 116, and subsequently figured and described by him in the Ann. and Mag. Nat. Hist. vol. iv. 2nd ser. 1849.-W. D.

WE notice with regret the death of Mr. A. G. BATN, who was the first to show by map and section, as well as by great collections of fossils, the geological structure of Cape Colony. He died at Cape Town, on the 20th October last, having just landed from England. 